\title{
Inclusive Education Management Peculiarities at Public Schools In Republic Of Armenia
}

\author{
Meline Grigoryan \\ Yerevan V. Brusov State University of Languages and Social Sciences 'Children of Armenia' Charitable Fund
}

\begin{abstract}
.
The purpose of this study was to investigate school factors influencing the implementation of inclusive education at public schools in Republic of Armenia. This study aimed:

- to examine the peculiarities of inclusive education management in the Armenian public primary schools

- to examine the main features of inclusive education in schools and to develop theoretical and practical ways for their improvement.

According to the purpose of the study, object and subject, the following problems have been identified:

1. Explore modern approaches to inclusive education management, legislative framework, legal justification, theoretical and methodological prerequisites,

2. Examine and analyze the management of the inclusive education setting,

3. Develop theoretical and practical ways of improving inclusive education management In this study 391 respondents participated, 57 of inclusive schools' principals, 107 viceprincipals, 49 headmasters and 94 teachers, 84 multidisciplinary team members, as of 234 $(59.8 \%)$ believe there are doing well and know about inclusive education process in a proper way, and $28(7.2 \%)$ were satisfactory, whereas $31(7.9 \%)$ respondents had a negative opinion on inclusive education management, 60 respondents (15.3\%) could not give a clear answer on inclusive education issues, they are mainly university students of BA 3rd and 4th and Master's 1st and 2nd year students, so the awareness level of the issues studied was low.
\end{abstract}

Keywords: research; respondents; teachers, principals; inclusive education setting 


\section{Introduction.}

In many countries around the world (USA, Russia, Israel, Germany, Finland, Sweden, etc.), as well in Armenia, one of the main issues of education, is learning, teaching and involvement of children with special educational needs which has a great importance and role in the educational system all over the world.

Socio-economic transformation of the society, the teacher education system reform, restructuring, each child's education right with emphasis to an appropriate education, compulsory education of the child's abilities is essential in the system of inclusive education in order to create, develop and improve the education of students with special educational needs and ways to get educated.

Therefore, at the present stage of the special educational needs of students in special and inclusive education system acquires a particular importance to the effective management of schools in corrective-developmental activities. However, theoretical and practical inadequacy and lack of such a problem essentially complicates the work of teaching, correcting and developing in special educational conditions, as well as organizing and conducting pedagogical approaches. Inclusive education management features, efficient means, methods and conditions for the development of skills and abilities of students with special educational needs study and development expertise will facilitate the development of students with special educational needs (Davis P., Florian, 2008) .

The problem of inclusive education and upbringing is a relatively new direction in special education and pedagogy, theory and practice of management of education. There are many studies/research in science-methodical literature dedicated to the co-teaching and educating of students in special conditions at basic/primary schools.

However, it is worth mentioning that the inclusion of special pedagogy, psychology, and education management have not yet received adequate scientific justification, together with theoretical and practical research. The structure of inclusive education in the general education sector is almost not studied, including the pedagogical conditions, the developed programs, the content, the methodological and psychological approaches for the peculiarities of effective management of inclusive education, as well as the peculiarities of adapting educational and rehabilitative work. Inclusive education management solutions and features for students with special needs are not covered in the basic education schools in special literature.

Inclusive education as a new challenge for the educational system and its social significance, insufficient elaboration of practical and theoretical, methodological rationale, content, organization, management, development and implementation of effective ways to emphasize the importance of the study and management.

The relevance of the research highlights the fact that until 2025, all schools in the Republic of Armenia should become an inclusive education institution according to the RA law on "General Education", the determination is to pass to universal inclusion. Consequently, 
effective and quality management of inclusive education is of great importance in the Armenian schools. ${ }^{1}$

Consequently, effective and quality management of inclusive education is of great importance in the Armenian schools.

Based on the above mentioned, the study of inclusive education in the field of general education in Armenia and the elaboration of effective ways of management, in practice, the justification of their effectiveness determines the scientific direction of the given research work.

The research Object is the Inclusive Education Management Process and the research subject is the methods, means and conditions for inclusive education management.

We assume that the inclusion of inclusive education management in Armenia's primary schools will be effective if:

- Examine inclusive education management activities;

- Study/examine the issues of the level of awareness of the schools' principals, viceprincipals, headmasters, teachers and multidisciplinary team members involved in the inclusive education process,

- Provide theoretical justifications for inclusive education management improvement,

- Introduce the main directions of interaction and cooperation of the specialists involved in the process of inclusive education.

The research objective is to explore the peculiarities of inclusive education management in Armenian primary schools and elaborate theoretical and practical ways of their improvement.

1.1. In the first sub-chapter titled "The essence and content of inclusive education" we touched upon the essence of inclusive education, ideology, as well as analyzed and presented the terminology of children with special educational needs, the development of effective opportunities for inclusive education that can be achieved through national strategy and policy formulation.

2. The second sub-chapter titled "Creating and Developing Inclusive Education in Armenia" presents a set of national and international law sources for the establishment and development of inclusive education in Armenia, as well as regulation.

2.1. The third sub-chapter under the heading "Issues of inclusive education management and their level of research in the scientific and methodological literature" describes the degree of the subject matter being studied in scientific literature, analyzes of inclusive education, but it is evident that the education system and the process need management. its imperfect condition and omissions.

2.2. The main focus of the research, problems and methods are based on fourth sub-chapter, entitled "The main focus of the research, problems, methods and stages of the research".

\footnotetext{
${ }^{1}$ RA Law on General Education Amendments, adopted on 01.12.2014, LA-200 Law
} 
According to it, the problem is ongoing, but not fully studied in our country, which complicates the process of organizing and managing the inclusive education process effectively. The study of the problem will enable the improvement of the relevant work.

3. The second chapter titled "Study of the Inclusive Education Management Framework in Armenia's Primary Schools" consists of three sub-chapters.

The first sub-chapter entitled "Legislative and Legal Framework for Inclusive Education Management Documentation, Analysis and Analysis of Documentation" provides an overview of the legislative and legal framework for inclusive education management in Armenia, the inclusive education management curriculum in schools, as well as on the inclusive education management of school principals, head teachers, teachers, multidisciplinary team members, Kh. Abovyan Armenian State Pedagogical University's 3rd and 4th year bachelor's and master's Level 1 and 2 nd year students' awareness.

The second sub-chapter entitled "Analysis of Inclusive Education Management in Primary Schools of RA" provides an overview of legislative, legal documents on inclusive education management in general education, which was implemented in Yerevan and Armavir, Aragatsotn, Tavush, Gegharkunik, Lori and Shirak regions at schools. The results of monitoring, organizing, organizing and conducting educational, learning, developmental activities in these schools are summarized. In this study 391 respondents participated, 57 of inclusive schools' principals, 107 vice-principals, 49 headmasters and 94 teachers, 84 multidisciplinary team members. The results of the survey show that the majority of respondents $(65.2 \%)$ considered the inclusive education management work to be quite significant, but only $82.4 \%$ of the interviewed school directors, $62.6 \%$ of the directors, $59.2 \%$ teachers and $63.8 \%$ teachers and professors, $58.3 \%$ multidisciplinary team members satisfactory and positively assessed the work they are doing on the problem examined (Table 1).

Table 1. Inclusive Education Management Assessments indicators

\begin{tabular}{|l|l|l|l|l|l|l|}
\hline \multirow{2}{*}{ Participants } & \multicolumn{4}{l}{ Assessments } \\
\cline { 2 - 8 } & \multicolumn{2}{l}{$\begin{array}{l}\text { positive and } \\
\text { satisfactory }\end{array}$} & \multicolumn{2}{l|}{ insufficient } & \multicolumn{2}{l|}{$\begin{array}{l}\text { could } \\
\text { answer }\end{array}$} \\
\cline { 2 - 8 } & $\mathrm{N}$ & $\%$ & $\mathrm{n}$ & $\%$ & $\mathrm{~N}$ & $\%$ \\
\hline 1 & 2 & 3 & 4 & 5 & 6 & 7 \\
\hline Principal $\mathrm{n}=57$ & 47 & 82.4 & 6 & 10.5 & 4 & 7.0 \\
\hline Vice-principal $\mathrm{n}=107$ & 67 & 62.6 & 30 & 28.0 & 10 & 9.3 \\
\hline
\end{tabular}




\begin{tabular}{|c|c|c|c|c|c|c|c|}
\hline Principals & $\begin{array}{l}\text { Vice } \\
\text { principals }\end{array}$ & \multicolumn{2}{|c|}{$\begin{array}{l}\text { Head } \\
\text { teachers }\end{array}$} & Teachers & \multicolumn{2}{|c|}{$\begin{array}{l}\text { Multidisciplinary } \\
\text { team }\end{array}$} & $\begin{array}{l}\text { UniveI } \\
\text { Stude }\end{array}$ \\
\hline \multicolumn{2}{|c|}{ Head teacher $n=49$} & 29 & 59.2 & 10 & 20.4 & 10 & 20.4 \\
\hline \multicolumn{2}{|c|}{ Teacher $n=94$} & 60 & 63.8 & 20 & 21.2 & 14 & 15.0 \\
\hline \multicolumn{2}{|c|}{ Multidisciplinary team $n=84$} & 49 & 58.3 & 22 & 26.2 & 13 & 15.4 \\
\hline \multicolumn{2}{|c|}{ Average index } & 50 & 65.2 & 17 & 21.3 & 10 & 13.4 \\
\hline
\end{tabular}

Under the heading "Study of the level of awareness of school staff on inclusive education management", sub-chapter 3 presents the level of awareness of school staff involved in inclusive education on inclusive education management. Data analysis suggests that education and upbringing processes for students special educational needs are being implemented, but inclusive education management practically does not work.

The study involved participants as mentioned above are 391 respondents, 57 directors of inclusive schools, 107 directors, 49 teachers and 94 teachers and professors, 84 multinational team members, 234 of whom (59.8\%) thought they had excellent and good inclusive education, and 28 (7.2\%) were satisfactory, whereas 31 (7.9\%) respondents had a negative opinion on inclusive education management. Of the respondents, $60(15.3 \%)$ failed to give a clear answer to inclusive education management issues. Kh. The 3rd and 4th Bachelor of Armenian State Pedagogical University after Abovyan also had a low level of awareness on the issues studied by 1st and 2nd year Master's students (Figure 1).

Figure 1. Indicators of awareness of respondents on inclusive education and inclusive education management issues

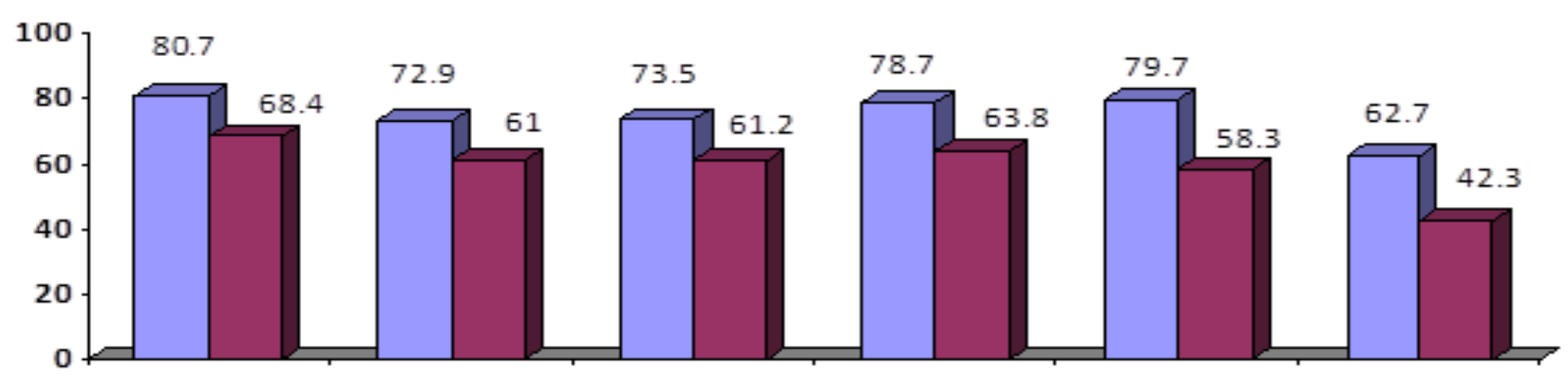


The third chapter, titled "Theoretical Approaches and Practical Ways to Improve Incorporation Education Management," consists of three sub-chapters (Grigoryan, 2016).

The first sub-chapter entitled "Theoretical Justification for the Necessity of Improving Integrated Education in the Primary School Inclusive Education" presents the need for theoretical and practical approaches, tools, methodological recommendations, which should focus on setting up conditions, structuring, work management of different content units in primary schools implementing inclusive education. as well as educational, psychological and pedagogical support of students or support for families of students with the level of development delays and so on.

The second sub-chapter titled "Management Principles for the Implementation of the Inclusive Education Process" introduces the technology of creating an inclusive educational process, which is a mandatory condition for the management structure of each department of the educational institution (educational, multidisciplinary team), the sequence of formation, for organizing all the processes in order, sequence.

As part of a school governance, which implements an inclusive education process, the institution should be equipped with highly qualified instructors, speech therapists, special educators, special psychologists and social educators. The choice of multidisciplinary team is of great importance because the quality of all educational and learning activities of the school is the result of the teamwork and joint work with the teachers, the parents of the students.

Under the heading "Basic Guidelines for Interaction Management of Primary School Education Processes Inclusive Education Process", the sub-chapter presents the main focus and peculiarities of the management of each specialist in the school of inclusive education.

The key focus of this kind of interaction is to help developers/practitioners and their parents to adapt to the new environment, build learning skills, control the developmental issues, prevent correction, secondary prevention, secondary school attendance, and more.

The management of interactive teachers and multidisciplinary team collaborators is mainly focused on the following three areas:

1. Interaction in students learning, which includes:

- Assist in the development of the student's learning process with the developmental delay (classroom perceptions, learning outcomes, teacher requirements, student activities, etc.), educational process, etc.

- Control and evaluate students ability to their actions.

- Support to the implementation of student strategy with developmental delay, from the extensive support to the slightest, from the "All Time With" provision, to the side "When Support and Support Needed," the principle of self-reliance.

- Plan the development of a student's individual learning with developmental delay.

2. Interaction in the correctional workshop and student socialization process, which affects to: 
- Development of individual learning curriculum for elimination and working with student's development delay.

- Selection of effective learning outcomes, methods, and conditions for the development of student development delay.

- Planning, organizing, and implementing student-focused exercises, taking into account the student's character, the degree of developmental delay and the form.

- Adaptation, adaptation of socialization process among classmates of developmental delay.

- Assistance in communication among students with disabilities and classmates, teachers, and other professionals for the development of communication skills and abilities.

3. Interaction with parents of student development during processes.

The main directions of the work are:

- System of Special Educators and Parent Processes aimed at the development of educational programs and socialization activities.

- Provision of training materials at home, development of notes for students and parents.

- Provide parent support in the inclusive education process so that he/she can realize his/her role in this aspect.

These are the main directions, forms and exemplary content of the interaction of the specialists of the school implementing inclusive education.

In this research we highlight the following such as ways of Managing the Individual Training Plan/ITP/ in the Inclusive Education System of Armenia, in which the Individual Training Plan should be administered in the RA inclusive education system, which addresses the importance and significance of the ITP, through which a number of critical processes can be implemented to address student learning and correctional and other activities, progress, overall effectiveness, and more.

On the basis of these findings we came to the conclusion that in the schools implementing inclusive education, it is necessary to organize and carry out work taking into account the inclusive education management approaches proposed by us. It contains a sequence of comprehensive steps to which each should pass

1. Primary assessment of student development

2. Multidisciplinary assessment of the student's psychological, physical development

3. Creation of a team for the development and functioning of the IEP

4. Development of the IEP

5. Implementation of the IEP 
6. IP Monitoring, Review and Review

\section{CONCLUSION}

Literature study and research conducted by us allowed the following conclusions:

1. The issue of inclusive education management has always been considered urgent and very important. This is evidenced by domestic and foreign literature, but incomplete theoretical and practical study of this issue in many cases significantly complicates the inclusive education management in Armenia's primary schools, and therefore suffers from educational and correctional work, support for pupils in need of special education, as well as the effectiveness of organizing and implementing all the activities of the inclusion process. Consequently, the comprehensive study of this issue, the elaboration of tools, methods and conditions for inclusive education management has a modern theoretical and practical significance, which determines the relevance of this topic.

2. It has been established that inclusive education has entered the Armenian educational system with the appropriate legal, legislative basis, and also annually revises and improves the legal framework for inclusive education. There are many decisions about inclusive education. In order to be effective, these documents lack information on the field of inclusive education, which needs development and improvement. The existence of all this will contribute to the organization, conduct and control of all the departments of inclusive education, educational, attentive, correctional, and more.

3. The inclusive education management curriculum has been identified in the primary schools of Armenia, the results of which show that all respondents (65.2) highly appreciate the importance of this work at school, the governance structure is at a low level and there are still some unresolved issues in this problem.

4. The level of awareness of principals, head teachers, teachers, and multidisciplinary team members involved in inclusive education process has been studied and disclosed in inclusive education management where the overwhelming majority of respondents rated their theoretical knowledge on inclusive education management issues (from $69.4 \%$ to $87.2 \%$ ) and $44 \%$ of the interviewed directors, $39.5 \%$ of the deputy directors, $43.6 \%$ teachers, $37.3 \%$ teachers and $60 \%$ professional staff team were able to visualize the basic tenets of inclusive education, the necessary documents, pedagogical issues to be discussed in the Pedagogical Council and so on.

5. The thesis features theoretical approaches and practical ways to improve the management of inclusive education,

- Theoretical justification for the need to improve the school's inclusive education management;

- Terms of management of the school implementing inclusive education;

- The main directions of the interaction of the specialists involved in the inclusive education process,

- The ways of managing the individual learning plan in the RA inclusive education system.

\section{Acknowledgement}


This research paper is an output of the science project being carried out within PhD research period.

\section{References}

[1] Davis P., Florian L. et al., (2004). Teaching Strategies and Approaches for Pupils with Special Educational Needs, A scoping study, Research Report 516, Department of Education and Vocational Training, London, $90 \mathrm{p}$.

[2] Grigoryan M., (2016). How to Manage Inclusive Classroom Effectively?, Special Education, Traditions and Innovations, Scientific ebook, Materials of International Scientific-Practical Conference, 12-14 April, Minsk, p. 14-21 